\title{
骨傷のない頸䯣損傷について
}

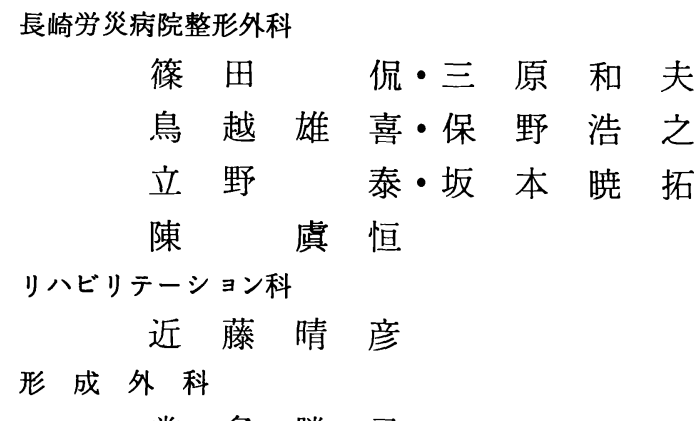

\section{Cervical Spinal Cord Injury Without Damage to Vertebrae}

By

T. Shinoda, K. Mihara, T. Torigoshi. H. Hono, Y. Tatsuno, A. Sakamoto \& G. Chen

Department of Orthopaedic Surgery Nagasaki Rosai Hospital

H. Kondo

Department of Rehabilitation

K. Tsuneta

Department of Plastic Surgery

Of about one hundred patients of cervical spinal cord injury experienced in our hospital since 1960 forth-three were out of damage to the vertebrae.

All patients except for nine in whom anterior fusion of the spines were performed were treated conservatively.

Three patients died of acute abdomen, insufficiency of respiration and hyperpyrexia, respectively.

According to ages, eliologies of injury, X-ray findings, activities of daily livings and results of operations our materials were studied.

\section{はじめに}

頸髄損傷が，脊損の中で占める割合が，増加してい るのは，全国的な傾向で，当科に於ても，昭和 45 年 頃より, 頸䯣損傷が增加し, 胸腰能道損傷より多くなっ ている. 頸部に，直接・間接に外力が作用し，頸髄損 傷が生じるわけであるが，乙の際，頸髄に，脱臼や骨 折が存在しないのに，頸䯑道損傷が認められる事が知ら
れている．われわれは，昭和 40 年より，当科にて治 療された，約 100 例の頸㖪損傷の中で， 43 例の本症 について, 検討したので, 述べる.

\section{1. 対象}

昭和 40 年より，現在までに，当科で治療された 43 例を対象とした．その内訳は，すべて男性であり，40 〜 49才の 11 症例をピークに, 平均年令 46.5 才であ 
った、レ線写真およびカルテのはっきりした，骨傷群 51 例之 比較すると, 骨傷群の平均年令が, 37.3 才で あり, 非骨傷群が, 比較的高令者にみられた（表 1 ).

表 1 頸䯣損傷（年令分布）

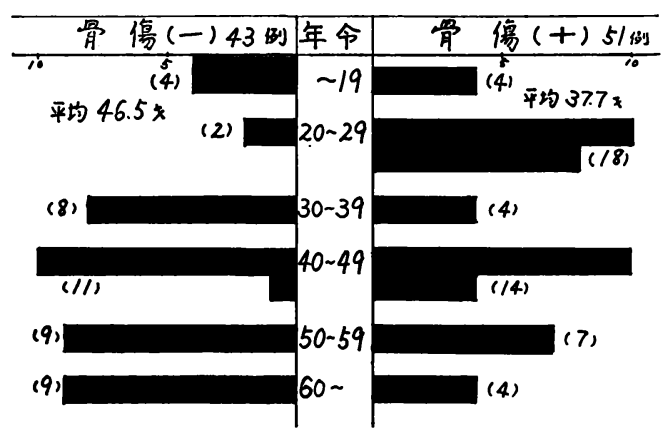

\section{2. 受僨原因および受僨機転}

受傷原因は，転落が最も多く, 約 $40 \%$ 占め, 以 下, 転倒, 亲通事故, 頭・頸部への落下物, スポーツ の順であった. 受傷書転として, 軸圧, 屈曲, 伸展, 可旋などの因子が考えられるが，乙れらの因子の単独 作用上よりあ複数伯相互に作用して損傷を生じる事が 多いと考ええられる. 本症については, 過伸展の要坂 が多いと考えられる. われわれの症例で, 明らかに, 過伸展損傷と考えられる症例は，9例であった.

\section{3. 病型の分類}

受傷後 $3 \sim 4$ 週して, 脊䯣および軟部組織の浮腫が 消退し, 確経根の neuroplaxia の状態が消失した時 点で, 神経学的所見より, 富永の分類に従って分類し た. 中心部損傷型, 12 例, Brown-Séquard 型, 4 例, 横断損傷型, 26 例（完全型 7 例, 不全型 19 例) で, 横断損傷型が, 最も多くみられた.

\section{4. 傷害レペル}

判定の時期については, 病型の決定と同じ時期に行 なった. C 523 例 (53\%), C 6 8例 (19\%), C 77 例 (16\%), C 82 例 ( $5 \%$ ), 尚, 傷害レ ベルは, 正常な最下部の㖪節をもって表わした.

\section{5. 椎管前後径比}

頸椎単純 X線側面像に於ける, 第 5 頸椎レベルでの 椎体椎管前後径比 $R$ を測定すると, 本症では，0.8 を ピークに, 平均 0.785 であり， 1.0 をピークとする正

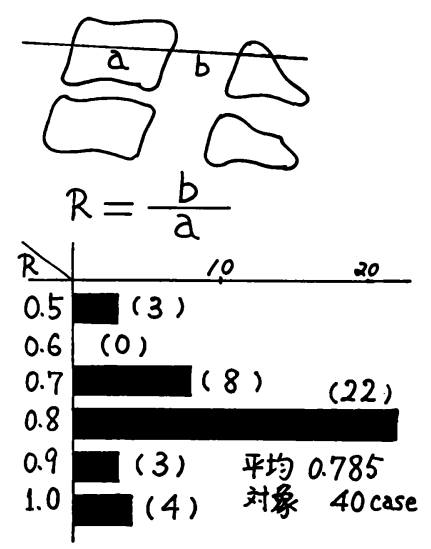

表 2 椎体椎間前後径比（科 5 頸椎）

常例よりも，狭小化の傾向がみられた．しかし， Rが 0.7 以下の椎管狭小例は, 11 例 $(28 \%)$ であった. (表 2 ).

各タイプ別の $\mathrm{R} の$ 平均值では，中心部損傷型 0.77 Brown-Séquard 型 0.75 , 横断損傷型で完全損傷型 0.79 , 不全損傷型 0.81 であり, 各型に有意の差はな かった.

\section{6. 賃 害 因子}

受傷時の X 線写真にて, 頸椎単純写真に, 次の上う な所見が得られた. 前方骨棘 5 例, 後方骨棘 12 例, 前綎勒帯骨化 6 例, 後縦勒帯骨化 3 例, 㾤合椎 2 例で あった. 正常 12 例を除いた 31 例すなわち $72 \%$ に, 頸椎に変形および異常が認ゆられた. このような頸椎 の既存の変形および異常が, 脊髄の易損性を高めてい ると考えられる。

\section{7. 治療および手術成䋶}

ほとんどが，保存的になされている．受傷より，約 4 週, 頭蓋直達率引を施行し, 除去後, 頸椎の前後屈 の機能撮影にて, 頸椎の不安定の有無を確認してい る. 手術例は, 9 例で, 43 例の $21 \%$ である. No. 3, No. 8 , No. 11, No. 17, No. 30 は, 受傷後 3 力月 すぎて, 当科へ入院した陳旧例である. 術式は, 前方 固定法で, Cloward 法単独, および, Smith-Robinson 法併用例である. 1 例のみ, 前方固定術後, 根 性疼痛が強く残存した症例に, 神経孔挔大術を追加し ている. 術後の成績判定については, 多くの判定基準 があるが, 充分なカルテの記載がなく, 今回は, 森の 
表 3 手 術 症 例（9例）

* 受倁後 $3 \mathrm{M}$ 以上(入院)経て

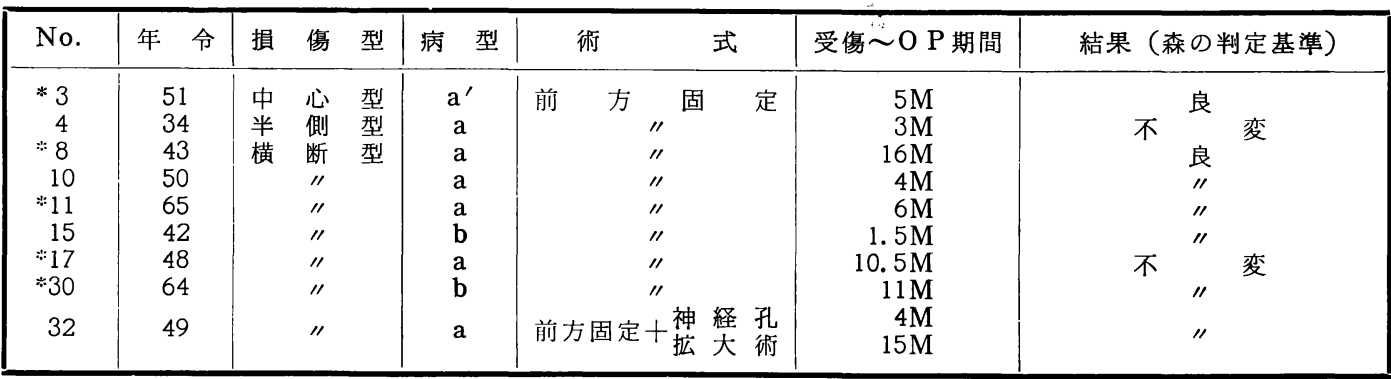

判定基準に従って判定した． 9 例中， 5 例に痛み， シ ビレの消失, 握力の増加, 歩行の改善などがみられ, 良と判定した。他 4 例は，不変であり，悪化した例 は，なかった（表 3 ）。

\section{8. 予後}

損傷タイプ別の ADL については，歩行は，中心 部損傷型が $50 \%$ ，独歩可能で，1例を除いて他は 松葉杖歩行が可能であった. 中心部損傷型は，下肢に ついては，良好な回復が得られるが，上肢に障害を残 す例が多い. Brown-Séquard 型は，すべて不全損傷 で，50\%が独歩可能となり，1例が車椅子使用を余 儀なくされ，飛事動作は，スプーン・サジおよび自助 具にて， $50 \%$ が一人で可能である，横断型では，40 \%が独歩可能で， $23 \%$ が松葉杖歩行，18\%が車椅子 使用可能で，残り $18 \%$ が，全く activity がなく， ほとんど，車椅子あ使えない状態であった.

\section{9. 考察}

非骨傷性頸䯣損傷は，レ線写真上，骨傷および脱臼 などの認められないもので，組織学的に，損傷がない ということではない. 発生機転に関しては, 多くの説 があるが，現在では，1951 年 Taylor の説が有力で ある. 彼は, 過伸展時に, 黄鞋帯の内方へのまくれ込 みを実験的に証明し，乙れが，前方部分の変性した椎 間板や骨棘と相互に作用して，春䯣損傷を生ぜしめる と述べている. Schneider によれば，乙の種の脊䯣 損傷は, acute central syndrome のタイプをとる ことが多いと述べているが，われわれの症例では，12 例で, 約 $28 \%$ あ゙あた. 予後の判定について, 完全 損傷か，不全損傷の判定を，48 時間（受傷後）に， 出現の有無を次の 5 項目についてチェックする事によ って決定している. (1) Bulbocavernosus Reflex
（球海綿体反射）（2） Anal wink（3） Perianal skin sensation (4) Rectal sphincter control (5) Toes flexion

\section{文献}

1）満足：整形外科. $27: 199,1976$.

2）富永：整形外科. $27: 97,1976$.

3) 富永：整形外科と災害外科. $23: 40$,

4) 今井：中部整災誌. 18:804.

質問 発言

山口大整形 服部 奨

(1)前方固定術に際し椎間板組織の後方への脱出例は なかったですか.

(2)御発表では椎弓切除例がないようですが，私たち は治療法として保存的治療 1 力月位後全く軽快の徴な き場合，ミエログラフィーを行ない， 1 ～椎間の範 井の通過障害が明らかな例には前方進入により，3 椎 間以上の例には椎弓切除（これにより明らかに効果を 認めた例あり）を行なう方針をとっていることを発言 します.

\section{解 答長崎労災 三原 和夫}

(1)われわれの症例の中の手術例で椎間板が，異常に 後方に突出していたという例はなかった.

(2)われわれの手術の対象にした患者は，臨床症状が 富永のいうCにランクされたものは除外し， b $\rightarrow \mathrm{a}$ を 期待しての手術対象である. このような患者では 3 椎 間以上も多発性に通過障害があるような例はないので 通常, 前方固定のみで目的を達している.

質 問

熊本労災 増田 良孝

(1)初診時所見として, 予後判定の上で, 有効と思わ れる, 検査・神経学的所見等についてお教え願いた い. 
(2)Convernam-sphinctor reflex は文献的は基告 よりも，曜効性（確実性）が少まいように思われるが どうか.

座長よりの質問に対し

(3)Sphinctor-reflex 等 現在, 早期予後判定のため のいくつかの検査法が出されているが， あまり確実性 は少ないように思われる. いずれにせよ，損傷部以下 の long-Truct sign 残存のみられる場合, ある程度 の希望があてるということしか言えないのではないだ ろうか.

解 答 長崎労災病院整形外科 篠田 㑆
独歩出来るようになる損傷の初診時の, impression. 初診時より経験した症例が少ないので, 特別に impression をもってない.

予後の判定については，受傷より 48 時間に，次の 5 項目をチェックすることによって，完全損傷か不全 損傷の判定の目安にしている.

(1) Bulbocarvernosus reflex

(2) Anal wink

(3) Perianal skin sensation

(4) Rectal sphincter control

(5) Toes flexion

\title{
Hangman's Fracture の 1 例
}

宮崎県立延岡病院整形外科
河 野 雅 行 - 永 田 高 見
谷 脇 功 一. 洞 田 光 司

\section{A Case of Hangman's Fracture}

By

\author{
M. Kawano, T. Nagata, K. Taniwaki \\ and K. Okada \\ Orthopedic Clinic, Miyazaki Prefectural \\ Nobeoka Hospital
}

\begin{abstract}
A school boy aged seventeen was involved in Hangman's fracture, in which he has the hyperextension of the upper cervical spine from diving. He has the severe neck pain and the temporary quadriplegia immediately after in ury.

Radiological sign showed the fracture of $C_{2}$ arch resulting from extension and compression of the upper cervical spine following a blow to the head, producing a Hangman's fracture, as suggested by Cornish (1968). Skull traction using Glisson's sling was applied with collar ten weeks after injury and anterior spinal fusion from $C_{2}$ to $C_{3}$ was performed eleven weeks after injury.
\end{abstract}

近年交通事故, 産業事故等の増加に伴い，いわゆる Hangman's Fracture の報告例が多数されている が，われわれは水泳の飛び込みによって発生した症例 を経験したので報告する.

$$
\text { 症例 }
$$

17 才男子高校生で, 生来 健康であり 既往歴には特
記すべき事は無い. 昭和 51 年 7 月 29 日海水浴場で, 高さ約 2 米の岩場から樑さ 1.5 米の海に飛び込んだと ころ前頭部に衝撃を受け, 直後より強い頸部痛と四肢 麻疸をきたし立ち上れなかった. 友人に助けられ某医 に運ばれた頃は頸部痛と四肢ジンジン感は有ったが, 四肢自動運動は可能であった. 